\title{
159. Die totale Pankreatektomie
}

\author{
M. Trede, K. H. Kersting und W. Storz \\ Chirurgische Klinik, Klinikum Mannheim der Universität Heidelberg
}

\section{Total Pancreatectomy}

Summary. The film shows a patient with obstructive jaundice due to carcinoma of the head of the pancreas to demonstrate the technique of total pancreatectomy, including preoperative diagnosis and postoperative care. In the 30 consecutive duodeno-pancreatectomies performed over the past 3 years ( 16 of them total pancreatectomies) mortality during surgery and during hospitalization has been nil.

Key words: Pancreas - Pancreatectomy, total.

Zusammenfassung. Der Film demonstriert am Beispiel eines Patienten mit Verschlußikterus durch Pankreaskopftumor das technische Vorgehen bei totaler Pankreatektomie, einschließlich präop. Diagnostik und postop. Nachbehandlung. Bei 30 konsekutiven Duodeno-Pankreatektomien der letzten 3 Jahre (16 davon totale Pankreatektomien) gab es weder eine Operations- noch Hospitalletalität.

Schlïsselwörter: Pankreas - Totale Pankreatektomie.

\section{Schalenprothese für das Hüftgelenk nach Wagner DBGM}

Aesculap-Werke AG, vormals Jetter \& Scheerer 7200 Tuttlingen und Prof. Wagner

Orthopädische Klinik des Wichernhauses, Altdorf

\section{Wagner Cup Prothesis for the Hip Joint (DBGM: German Registered Design)}

Summary. A new technic is available for the operative correction of severe coxarthrosis especially for younger patients-with Dr. Wagner's cup prothesis; it avoids numerous problems of the traditional total endoprothesis. This new alloplastic cup prothesis replaces only the joint surfaces, the joint bodies being preserved. This replacement of the joint surfaces-a metal cup for the femur head and a polyethylene cup for the acetabulum-offers genuine opportunities for reversal, as in the case of failure all other alternative operations are still possible.

Key words: Osteosynthesis - Endoprothesis, hip.

Zusammenfassung. Für die operative Versorgung der schweren Coxarthrose insbesondere auch im jüngeren Lebensalter, steht mit der Schalenprothese nach Prof. Wagner ein neues Verfahren zur Verfügung, welches zahlreiche Probleme der konventionellen Totalprothese umgeht. Mit diesem neuen alloplastischen Gelenkersatz werden nur die Gelenkflächen ersetzt, so daß die Gelenkkörper erhalten bleiben. Dieser Gelenkflächenersatz, bestehend aus einer Metallschale für den Hüftkopf und einer Polyäthylenschale für die Hüftpfanne, bietet echte Rückzugsmöglichkeiten, da nach einem Versagen alle sonst verfügbaren Alternativeingriffe noch Anwendung finden können.

Schliisselwörter: Osteosynthese - Hüftgelenkprothese. 